\title{
Differential expression of duck Toll-like receptor 7 (dTLR7) in various organs of indigenous ducks
}

\author{
K. Gautham ${ }^{1}$, N. Ramamurthy ${ }^{1}$, R. R. Churchil ${ }^{2}$ and T. R. Kannaki ${ }^{3}$
}

1. Department of Poultry Science, Madras Veterinary College, Tamil Nadu Veterinary and Animal Sciences University, Vepery, Chennai - 600007, Tamil Nadu, India; 2. Institute of Poultry Production and Management, Tamil Nadu Veterinary and Animal Sciences University, Madhavaram Milk Colony, Chennai - 600051, Tamil Nadu, India; 3. Avian Health Laboratory, Directorate of Poultry Research, Rajendranagar, Hyderabad - 500030, Andhra Pradesh, India Corresponding author: K. Gautham, email: drgkpsc@gmail.com

Received: 28-07-2013, Revised: 30-09-2013, Accepted: 01-10-2013, Published online: 06-11-2013

doi: 10.14202/vetworld.2013.931-935

How to cite this article: Gautham K, Ramamurthy N, Churchil RR and Kannaki TR (2013) Differential expression of duck Toll-like receptor 7 (dTLR7) in various organs of indigenous ducks, Veterinary World 6(11): 931-935.

\begin{abstract}
Aim: The present molecular study was taken up with an aim of investigating the expression profile of duck TLR7 mRNA in various tissues of indigenous ducks of Tamil Nadu.

Materials and Methods: A total of 36 ducks which are reared in extensive system have been chosen as research material for the present experiment. Ducks were sacrificed and tissue samples namely lungs, spleen and gastrointestinal tract (duodenum, jejunum, ileum and caecum) were collected in RNA later solution. Total RNA was extracted and converted to cDNA. Gene specific primers were designed and quantitative SYBR Green based Real-time Reverse Transcriptase PCR (qRT-PCR) was performed to study the gene expression levels. The qRT-PCR data was normalized to $\beta$-actin, house keeping gene as endogenous control.
\end{abstract}

Results: Real-time quantitative RT-PCR analysis revealed higher expression in lungs and spleen, while expression being lower in digestive organs. Among gut associated tissues, ileum showed highest expression followed by caecum. Statistically no significant difference $(\mathrm{P}<0.05)$ in TLR7 expression was found between duodenum and jejunum.

Conclusion: These findings have indicated that considerable level of $d T L R 7$ is expressed in different tissues of ducks. The results suggest that TLR7 mediated innate immune response mechanism exists in native ducks, to fight against single stranded RNA viruses.

Key words: immune response, indigenous ducks, real-time qRT-PCR, Toll-like receptor 7.

\section{I ntroduction}

Ducks are considered important next only to chicken. India has a population of 26 million ducks [1] of which 90 to 95 per cent constitutes indigenous or nondescript type. Ducks, especially the indigenous type are resistant to many diseases despite their frequent exposure to marshy and grazing areas where the incidence of potential pathogens is relatively high. This might be due to their inbuilt strong innate immune response. Ducks and chicken are considered as important hosts for avian influenza virus, however, avian influenza H5N1 strains, which are highly pathogenic for chicken, rarely harm ducks [2]. Toll-like receptor (TLR) signalling pathway is one of the most critical and by far the best characterized mechanism of innate immune system [3]. TLRs are germ line encoded receptors belonging to a family of evolutionary conserved type-I transmembrane glycoproteins [4]. The activation of TLRs follows recognition and interaction with a wide range of markers of invading pathogens called Pathogen Associated Molecular Patterns (PAMPs) [5].

TLR7 is a member of the Toll-like receptor (TLR)

Copyright: The authors. This article is an open access article licensed under the terms of the Creative Commons Attribution License (http://creativecommons.org/licenses/by/2.0) which permits unrestricted use, distribution and reproduction in any medium, provided the work is properly cited. family and plays a fundamental role in pathogen recognition of single stranded virus RNA and activation of innate immunity. Acts via TIR domain containing adapter, myeloid differentiation factor 88 (MYD88). Triggering of TLR7 results in rapid up regulation of proinflammatory cytokines and interferons (IFNs) which are critical mediators of viral defense. TLR7 and TLR8 respond to U-rich singlestranded RNA (ssRNA), and are pathogen recognition receptors (PRRs) for the influenza [6]. In duck, only TLR7 gene has been characterized molecularly [7] and its gene expression has been investigated by several authors [8,9]. An understanding of TLR expression pattern in different tissue samples will allow more refined interpretation of immune induction and host pathology relationships [10], and also highlight the role of TLRs in enhancement of immune status in indigenous ducks reared under free range system, where they are exposed to marshy areas with high microbial load and their feeding habit is scavenging. However, there is a paucity of information regarding expression of TLR7 in ducks especially native type. Therefore this study was taken up with an objective of assessing the differential expression of TLR7 in various organs in native ducks of Tamil Nadu.

\section{Materials and Methods}

Ethical approval: The present investigation was carried 
Table-1. Characteristics of primers used for real-time PCR

\begin{tabular}{cccc}
\hline Genes Primer sequences & Product size & $\begin{array}{c}\text { Accession } \\
\text { No. }\end{array}$ \\
\hline TLR7 & 5' GTC GCC TCA CAG AAGTCC CCA3' (FP) & $156 \mathrm{bp}$ & DQ888644 \\
5' CCA ACC TGA CAG GCACGC AGT3'(RP) & & \\
$\beta$ actin 5' CCG TAA GGACCT GTACGC CAA3'(RP) & 208bp & AY251275 \\
5' GCT GAT CCA CAT CTGCTG GAA5'(RP) & & \\
\hline
\end{tabular}

FP- Forward primer; RP- Reverse Primer

out on native ducks of Tamil Nadu $(n=36)$ as per the Institute Animal Ethics Committee recommendations.

Experimental birds: Ducks were reared in extensive system during the entire study period at Nemeli, Arakkonam (India) up to 26 weeks of age, with access to pond and free range area. Ducks $(n=36)$ were chosen randomly and tissues are collected at the end of study period (26 weeks). No vaccination was done during study period. Tissue samples namely lymphoid organs (spleen), lungs and intestinal organs (duodenum, jejunum, ileum, and caecum) were collected in RNA later solution (Sigma-Aldrich).

RNA isolation and cDNA synthesis: Total RNA was isolated from the collected tissues using TRI Reagent (Sigma-Aldrich, USA). The preliminary concentration and purity of the extracted RNA was measured at 260 and $280 \mathrm{~nm}$ using the BioPhotometer plus (Eppendorf). Subsequently, an in-solution DNase digestion step (RNase free DNase I, MBI Fermetas, USA) was performed to avoid genomic DNA contamination. The quality and integrity of total RNA was checked using denaturating $1 \%$ agarose gel electrophoresis and visualization under UV light (Figure-1). Two intact bands of $28 \mathrm{~S}$ and $18 \mathrm{~S}$ with smearing indicated good quality RNA. cDNA was synthesised using oligo (dT) 15 primers and High-capacity cDNA reverse transcriptase enzyme (Applied Biosystems, USA).

Primers: Gene specific primers for both dTLR7 and $\beta$ actin (Table-1), used in this study were designed and custom synthesized from Integrated DNA Technologies (USA) and ILS (India).

Real-time quantitative RT- PCR expression study: All the protocols for Real-time qRT-PCR were carried as per the guidelines of MIQE (Minimum Information for Publication of Quantitative Real-Time PCR Experiments). Quantitative expression analysis was performed on diluted cDNA using Mx-3000P spectrofluorometric thermocycler (Stratagene, USA) in real-time PCR strips (Axygen). A total volume of reaction mixture containing forward and reverse primer (each 20 picomolar concentration) and nuclease free water (sufficient quantity)was prepared. Quantitative RTPCR thermal cycler conditions were set at initial denaturation at $95^{\circ} \mathrm{C}$ for $10 \mathrm{~min}$ followed by 40 cycles of denaturation at $94^{\circ} \mathrm{C}$ for $15 \mathrm{~s}$, gene specific annealing at $55^{\circ} \mathrm{C}$ for $10 \mathrm{~s}$, extension at $72^{\circ} \mathrm{C}$ for $30 \mathrm{~s}$.
Table-2. Differential tissue expression of TLR7 in native ducks of Tamil Nadu

\begin{tabular}{lcl}
\hline Organ & Sample size(n) & Mean $\mathbf{4 0}-\Delta$ Ctvalue \pm SE \\
\hline Spleen & 36 & $37.90^{\circ} \pm 0.23$ \\
Lungs & 36 & $37.93^{\mathrm{c}} \pm 0.33$ \\
Duodenum & 36 & $34.54^{\mathrm{ab}} \pm 0.44$ \\
Jejunum & 36 & $34.85^{\mathrm{ab}} \pm 0.57$ \\
lleum & 36 & $36.47^{\mathrm{b}} \pm 0.36$ \\
Caecum & 36 & $35.81^{ } \pm 0.49$ \\
\hline
\end{tabular}

Mean values bearing different superscripts differ significantly $(P<0.05)$. ab indicates no significant difference; $b$ and $c$ indicates lower and higher values respectively

Subsequent melting curve standards was performed to melt primer dimers by heating to $94^{\circ} \mathrm{C}$ for $30 \mathrm{~s}$ followed by $55^{\circ} \mathrm{C}$ for $1 \mathrm{~min}, 94^{\circ} \mathrm{C}$ for $30 \mathrm{~s}$ and $25^{\circ} \mathrm{C}$ for $10 \mathrm{~s}$. Samples were run in triplicate with no template control (NTC) included for both TLR7 and $\beta$-actin, to check the DNA contamination. Primer amplification efficiency was assessed for each gene from the generated standard curves using serial ten-fold dilution of transcribed RNA in sterile RNase-free water. Regression analysis of the $\mathrm{Ct}$ values of standard curve was done to calculate slope and amplification efficiency. Threshold cycle $(\mathrm{Ct})$ values of the PCRs that are in triplicate were averaged and expressed as $40-\Delta \mathrm{Ct}$ mean values. The higher $40-\Delta \mathrm{Ct}$ value can be interpreted as a numerical value indicating greater gene expression [11, 12].

Statistical analysis: All the statistical analysis were performed using SPSS software (version 16.0 upgraded, Inc, Chicago, IL.). One way Analysis of Variance (ANOVA) with Duncan's post-hoc test was performed. Results are expressed as means $\pm \mathrm{SE}$, and the differences are considered statistically significant at $\mathrm{P}<0.05$, and highly significant at $\mathrm{P}<0.01$.

\section{Results}

In the present study, we provide a comparative quantification of constitutive expression of TLR7 in various organs of native ducks. TLR7 under investigation could be amplified from all the tissues studied. Realtime quantitative RT-PCR analysis revealed significant $(\mathrm{P}<0.05)$ difference in various organs studied with regard to TLR7 expression (Table-2). Regression analysis of the $\mathrm{Ct}$ values generated by the $\log _{10}$ dilution series gave slope values for all reactions in the range of -3.53 for TLR7 and -3.15 for $\beta$-actin with the amplification efficiencies of $92 \%$ and $108 \%$ respectively. Among all the organs studied, lungs and spleen showed significantly higher $(\mathrm{P}<0.05)$ expression for TLR7 than digestive organs. Within the gastrointestinal tract, expression in various parts was studied and a considerable difference in TLR7 expression was noticed. Significantly, highest expression was recorded in ileum $(36.47 \pm 0.36)$, followed by caecum (Figure-2). No significant $(\mathrm{P}<0.05)$ difference was found statistically, between duodenum and jejunum. Gut associated tissues also exhibited lower TLR7 expression than spleen and lungs, but with a variation in expression pattern among themselves. 


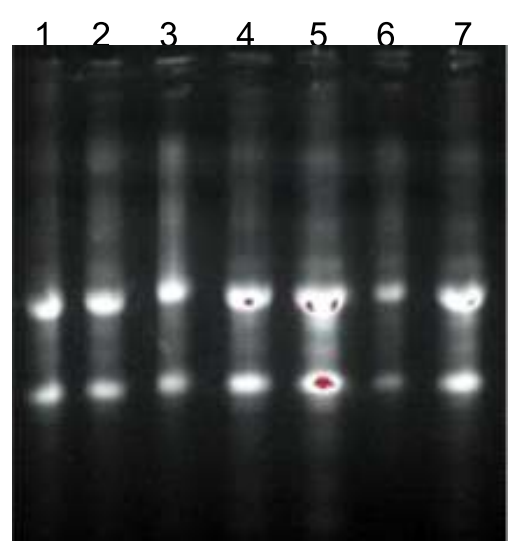

Figure-1. Gel showing integrity of total RNA sample isolated from duck tissues.

Lane 1, 2, 3, 6, 7: Known positive control; Lane 4 and 5: RNA bands from tissue sample

\section{Discussion}

Expression profile of TLR7 in lungs and spleen: Our findings of elevated TLR7 expression in lungs and spleen are in tune with the reports of [7,10,13]. Iqbal, et al. [10] and Yilmaz, et al. [17] reported constant and even level of expression in chicken. On contrary, Philbin, et al. [13] reported very weak expression of TLR7 transcripts in lung of chicken. This might be due to species variation (genomic organization) as galliformes and non galliformes. The later has presence of more resident cells expressing the TLR7 receptor, whilst the same are absent in the chicken [7]. Higher TLR7 expression in lungs of native ducks in this investigation could be comparable to that of TLR7's higher expression found in the lungs of human beings [14]. Assuming the role of TLR7 against single stranded RNA viruses like avian influenza in ducks, this high pulmonary expression in lungs could be significance in the context of highly pathogenic H5N1 avian influenza, which is primarily a lung infection [15] and replicates in the respiratory tract of ducks [16].

While in spleen it is important because of the poorly developed avian lymphatic vessels and nodes [18]. Higher expression in spleen might be due to high immune response activity and this is necessary to ensure optimum disease resistance. It is likely that the lungs and spleen of indigenous ducks in free range might be sensitive to TLR7 ligand by virtue of its expression as this tissue interfaces with pathogens that enter through it.

Expression of TLR7 in gastro intestinal tract: Intestinal epithelium, which is continually exposed to a large variety of commensal bacteria and PAMP, has been shown to constitutively express several members of the TLR in vitro and in vivo [20,21,22].The current investigation showed a comparatively lower TLR7 expression in gut associated tissues than spleen and lungs, and are similar with reports of Philbin, et al. [13] and MacDonald, et al. [8]. However, a variation exists among different parts of intestine. Several investigations on TLR7 expression in chicken were reported, but

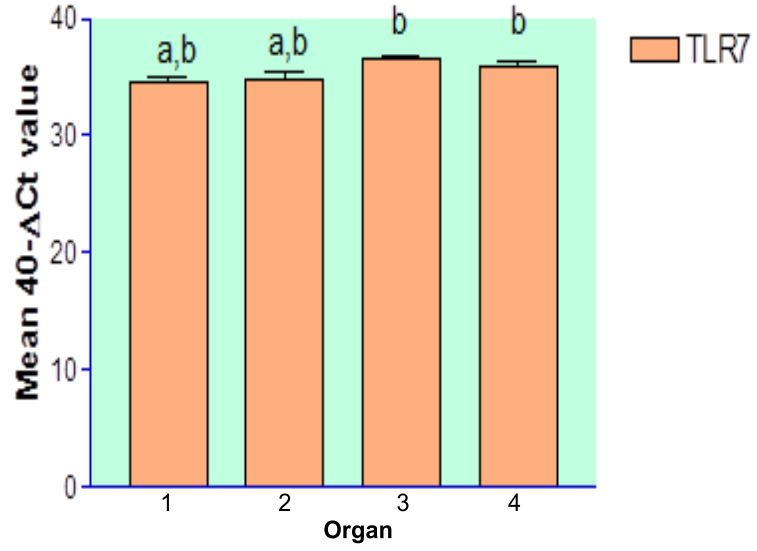

Figure-2. Expression pattern of Toll-like Receptor 7 in gastrointestinal tract 1) Duodenum; 2) Jejunum; 3) Ileum and 4) Caecum. $a b$ indicates no significant difference $b$ indicates higher value.

studies on duck TLR7 are lacking. Previous reports $[10,13,18]$ on chicken indicated more or less similar expression pattern of TLR7 in various gut associated tissues while this study indicates variation among different parts of intestine. We observed a similar expression in duodenum and jejunum. The lowest TLR7 expression in duodenum is in agreement with the previous finding [7]. The relatively higher TLR7 expression in ileum and caecum is an indirect indication of presence of more immune cellular receptors (enterocytes and peyer's patches) [23]. This dominant expression could be due to more mean retention time of feed than duodenum and jejunum [24] may perpetuates TLR7 due to high antigenic exposure to intestinal epithelium. Vandervena, et al. [25] have confirmed that immune response differs in ducks depending upon strain of virus that alters the TLR7 expression. These results correlate with an earlier studyin chicken [11]. The distribution pattern of enterocytes of intestinal tract, those interface with the contents of the gut lumen by virtue of their expression of Toll-like receptors in mammalian species [26] including poultry [27] can also influence the induction of enteric immune responses that probably reflects their role in early detection of invading microorganisms. The tissue and cell distribution is an important characteristic of TLR function, since it influences the capacity to detect microorganisms during their entry and growth in different target tissues [28].

\section{Conclusion}

Expression profiling for the presence of TLR7 transcript in different cells and tissues is an important feature that would characterize the ability of these cells and tissues in detecting pathogens. The variation in TLR7 expression in different tissues under study might be due to differences in the organization of lymphoid tissue and also the presence of resident cells expressing the TLR7 receptor. The results of the present basic study provide new knowledge about the innate immune mechanisms of the duck. As a whole, we conclude that Toll-like receptor 7 expression which plays a role in the 
recognition of single stranded RNA viruses, exists in different tissues of native ducks of Tamil Nadu. Higher TLR7 expression profile is suggestive of an individual's ability to respond to viral challenge. However, future studies may focus on other relevant innate immune genes in ducks with a viral challenge to arrive at specific recommendations.

\section{Authors' contributions}

GK carried out the research work, sample analysis, revision of manuscript and statistical analysis. NR and RRC designed the research work and provided guidance in writing the manuscript. TRK provided the technical guidance and methodology. All authors read and approved the final manuscript.

\section{Acknowledgments}

Authors are thankful to Madras Veterinary College, Tamil Nadu Veterinary and Animal Sciences University, Chennai, India for providing fund and facilities and Project Directorate on Poultry for supporting with facilities to carry out this work.

\section{Competing interests}

The authors declare that they have no competing interests. Mention of commercial products is for the sole purpose of providing speci?c information and not a recommendation.

\section{References}

1. Jalaludeen, A. (2012) Prospects of duck production for food and social security in India. In the proceedings of: National symposium on commercial and rural poultry production: Novel concepts and strategies to meet growing demand and changing consumer needs at Project Directorate on Poultry, Hyderabad, Andhra Pradesh 5-7 December.

2. Hulse-Post, D.J., Ramirez, K.M.S., Humberd, J., Seiler, P., Govorkova, E.A., Krauss, S., Scholtissek, C., Puthavathana, P., Buranathai, C., Nguyen, T.D., Long, H.T., Naipospos, T.S.P., Chen, H., Ellis, T.M., Guan, Y., Peiris, J.S.M., and Webster, R.G. (2005) Role of domestic ducks in the propagation and biological evolution of highly pathogenic H5N1 influenza viruses in Asia. Proceedings of National Academic Sciences, U.S.A.102(30):10682-10687.

3. Cormican, P., Lloyd, A.T., Downing, T., Connell, S.J., Bradley, D and Farrelly, C.O. (2009) The avian Toll-like receptors pathway- Subtle differences amidst general conformity. Developmental and ComparativeImmunology, 33:967-973.

4. Kannaki, T.R., Reddy, M.R., Shanmugam, M., Verma, P.C and Sharma, R.P. (2010) Chicken Toll-like receptors and their role in immunity. World's Poultry Science Journal, 66:727-739.

5. Abasht, B., Kaiser, M.G and Lamont, S.J. (2008) Toll-like receptor gene expression in caecum and spleen of advanced intercross line chicks infected with Salmonella enterica serovar enteritidis. Veterinary Immunology and Immunopathology, 123:314-323.

6. Lund, J.M., Alexopoulou, L., Sato, A., Karow, M., Adam, N.C., Gale, N.W., Iwasaki, A and Flavell, R.A. (2004) Recognition of single-stranded RNA viruses by Toll-like receptor 7. Proceedings of National Academic Sciences U.S.A, 101(15): 5598-5603.

7. Macdonald, M.R.W., Xia, J., Smith, A.L and Magor, K.E. (2008) The duck Toll-like receptor 7: Genomic organization, expression and function. Molecular Immunology, 45: 2055-2061.

8. Adams, S.C., Xing, Z., Li, J. and Cardona, C.J. (2009)
Immune-related gene expression in response to H11N9 low pathogenic avian influenza virus infection in chicken and Pekin duck peripheral blood mononuclear cells. Molecular Immunology, 46:1744-1749.

9. Liang, Q., Luoa, J., Zhoua, K., Dongc, J. and Hea, H. (2011) Immune-related gene expression in response to $\mathrm{H} 5 \mathrm{~N} 1$ avian influenza virus infection in chicken and duck embryonic fibroblasts. Molecular Immunology, 48: 924-930.

10. Iqbal, M., Philbin, V.J. and Smith, A.L. (2005) Expression patterns of chicken Toll-like receptor mRNA in tissues, immune cell subsets and cell lines. Veterinary Immunology Immunopathology, 104: 117-127.

11. Mackinnon, K.M., He, H., Nerren, J.R., Swaggerty, C.L., Genovese, K.J. and Kogut, M.H. (2009) Expression profile of Toll-like receptors within the gastrointestinal tract of 2 day old Salmonella enteritids-infected broiler chickens. Veterinary Microbiology, 137: 313-319.

12. Kannaki, T.R., Reddy, M.R., Raveendranathan, D.N., Murugesan, S., Chatterjee, R.N., Ullengala, R. and Haunshi, S. (2010) Differential expression of Toll-like receptor mRNA in white leghorn and indigenous chicken of India. Veterinary Research Communications, 34: 633-639.

13. Philbin, V.J., Iqbal, M., Boyd, Y., Goodchild, M.J., Beal, R.K., Bumstead, N., Young, J. and Smith, A.L. (2005) Identification and characterization of a functional, alternatively spliced Toll-like receptor 7 (TLR7) and genomic disruption of TLR8 in chickens. Immunology, 114:507-521.

14. Zarember, K.A. and Godowski, P.J. (2002) Tissue expression of human Toll-like receptors and differential regulation of Toll-like receptor mRNAs in leukocytes in response to microbes, their products, and cytokines. Journal of Immunology, 168:554-561.

15. Pantin-Jackwood, M.J. and Swayne, D.E. (2007) Pathobiology of Asian highly pathogenic avian influenza H5N1 virus infections in ducks. Avian Diseases, 51: 250-259.

16. Sturm-Ramirez, K.M., Hulse-Post, D.J., Govorkova, E.A., Humberd, J. and Seiler, P. (2005) Are ducks contributing to endemecity of highly pathogenic H5N1 influenza virus in Asia? Journal of Virology, 79: 11269-11279.

17. Yilmaz, A., Shen, S., Andelson, D.L., Xavier, S. and Zhu, J.J. (2005) Identification and sequence analysis of chicken Tolllike receptors. Immunogenetics, 56: 743-753.

18. Olah, I. and Vervelde, L. (2008) Structure of the avian lymphoid system. In: F. Davison B. Kaspers, K.A. Schat (Eds.), Avian Immunology, Academic Press, London, 13-50.

19. Korver, D.R.(2006). Overview of the Immune Dynamics of the Digestive System. Journal of Applied Poultry Research, 15:123-135.

20. Cario, E and Podolsky, D.K.(2000) Differential alteration in intestinal epithelial cell expression of Toll-like receptor 3 (TLR3) and TLR4 in inflammatory bowel disease. Infection Immunity. 68: 7010 -7017.

21. Melmed, G., Thomas, L.S, Lee, N., Tesfay, S.Y, Lukasek, K, Michelsen, K.S., Zhou, Y., Hu, B., Arditi, M and Abreu, M.T.(2003) Human intestinal epithelial cells are broadly nresponsive to Toll-like receptor 2-dependent bacterial ligands: implications for host-microbial interactions in the gut. Journal of Immunology, 170: 1406-1415.

22. Nanthakumar, N.N., Dai, D., Newburg, D.S and Walker, W.A. (2003) The role of indigenous microflora in the development of murine intestinal fucosyland sialyltransferases. The Journal of the Federation of American societies for Experimental Biology, 17: 44-46.

23. Forchielli, M.L. and Walker, W.A. (2005) The role of gutassociated lymphoid tissues and mucosal defence. British Journal of Nutrition, 93(1): S41-S48.

24. Shires, A., Thompson, J.R., Turner, B.V. and Kennedy, P.M. (1987) Rate of passage of corn-canola meal and cornsoybean meal diets through the gastrointestinal tract of broiler and White Leghorn chickens. Poultry Science, 66: 289-298.

25. Vandervena, H.A., Petkaua, K., Ryan-Jeana, K.E.E., Aldridge Jr, J.R., Webster, R.G. and Magor, K.E. (2012) Avian influenza rapidly induces antiviral genes in duck lung 
and intestine. Molecular Immunology, 51:316-324.

26. Gewirtz A.T., Navas, T.A., Lyons, S., Godowski, P.J and Madara, J.L.(2001) Cutting edge: bacterial ? agellin activates basolaterally expressed TLR5 to induce epithelial proin? ammatory gene expression. Journal of Immunology, 167: 1882-1885.

27. Smith, L and Beal, R.(2008) The avian enteric immune system in health and disease, in: Davison, F., Kaspers, B., Schat, K.A. (Eds) Avian Immunology, pp. 243-271(London, Academic Press, Elseiver).

28. Dhinakar Raj, G., Rajanathan, T.M.C., Kumanan, K. and Elankumaran, S. (2009) Expression profile of Toll-like receptor $m$ RNA in an indigenous aseel breed of chicken in India. International Journal of Poultry Science. 8(7):651-655.

$* * * * * * * *$ 